\title{
TAX AVOIDANCE AND TAX EVASION IN EU: TRENDS AND EFFECTS
}

\author{
Emil Gheorghe GUIAȘ, Codruța Mihaela HĂINEALĂ \\ Doctoral School of Economic Sciences, Faculty of Economic Sciences, University \\ of Oradea, Oradea, Romania \\ guiasemil@gmail.com \\ codruta.haineala@gmail.com
}

\begin{abstract}
The main purpose of this article is to study the concept and aspects of tax avoidance and tax evasion, their causes, trends and effects in the European Union(EU). In recent years, the debate on international tax policy has focused on tax avoidance strategies and tax evasion. Cases of tax evasion and tax evasion have become increasingly common. These phenomena were triggered by several factors. Some of them relate to European principles such as those relating to the free movement of persons, goods and capital, which led to the diversification and complexity of trade, under conditions of imperfect legislation. Other factors are the social and economic ones generated by the onset of the economic crisis. Another set of factors that have been favorable circumstances for the development, the phenomenon of tax avoidance and tax evasion, are those related to the degree of taxation that differs from one-member country to another and different tax systems. This expansion of the phenomenon of tax avoidance and tax evasion generates negative effects on the European economy, which are making their mark on the economy. In this context, concerns have arisen at EU level to create a legislative framework to mitigate these phenomena. As these two phenomena (tax avoidance and tax evasion) cannot be completely eradicated, it is very important to find the most efficient measures to combat them. Another element specific to the European Union that generates tax evasion and tax avoidance is Value Added Tax (VAT). As with any tax, Value Added Tax presents opportunities for tax avoidance and evasion. European Union experts believe that tax avoidance and tax evasion are important factors limiting revenue mobilization. Tax evasion and tax avoidance affect us all. ese phenomena occur both within a country and within the European Union, but also globally. That is why one country cannot solve the problem alone. The European Union and the Member States must work more together and at international level to combat the problem in the country within the Union but also outside the borders of the European Union. Thus, in principle, legislators can affect the decisions of the subjects by defining the boundary between legality and illegality. The purpose of this paper is to investigate the trends and effects resulting from tax avoidance and tax evasion behavior.
\end{abstract}

Keywords: tax avoidance, tax evasion, tax fraud, VAT evasion, underground economy

JEL Classification: H2, H6 


\section{Introduction}

Both tax evasion and tax avoidance are a large-scale economic and social phenomenon of great magnitude and importance that many states face, to a greater or lesser extent. The size and causes of these two phenomena differ from one geographical region to another. In the case of the European Union we can talk about it as a geographical queen, but also within this area there are big differences from one country to another in terms of size and causes of the phenomenon of tax evasion or tax avoidance. The existence of a large number of tax obligations, as well as their size, have constantly generated tendencies to avoid or evade taxation. Given the causes and proportions of tax evasion and tax avoidance, and whatever the control measures are, can't talk, in terms of the results obtained, about eradicating this phenomenon, one can only talk about its limitation. The phenomenon of tax evasion and tax avoidance are an integral part of the underground economy, being present in all areas of income-generating activities. Legislative inconsistencies and gaps in the European Union as well as different taxation from one country to another stimulate the taxpayer's ingenuity, causing him to seek and apply various procedures to circumvent the law and optimize his business so as to pay as few taxes and duties as possible.

While tax planning strategies that use complex group structures to minimize a company's tax burden without violating tax laws can be morally reprehensible or highly questionable, they are not illegal, newspapers report evidence of extensive tax avoidance activities by multinational corporations almost daily (Lisowsky, 2010).

The creation and maintenance of public infrastructure and the provision of government services is a key factor for economic development. Within the European Union, there are big differences between the degree of development of the countries that make it up.

In many countries of the Union with a lower degree of development, the lack of public service provision slows down economic growth and undermines efforts to improve the living standards of the population. There are a number of explanations, one of which is the lack of tax revenue.

In recent years, the academic and political debate on development finance and development aid has raised the issue that tax avoidance and tax evasion could undermine the capacity of European Union countries and especially of less developed countries to finance their public sectors. This view is based, inter alia, on the perception that the underground economy in these countries is larger than in those with a higher degree of development. The term "underground economy" does not have a universally accepted definition. In the context of taxation and revenue mobilization a useful definition of "underground economy" would include undeclared income from the production of legal goods and services, either from monetary or barter transactions, so all economic activities that would generally be taxable, if they were reported to the tax authorities (Friedrich, and Dominik, 2000). Tax evasion is possible by capitalizing on elements with high tax risk. The globalization of the economy of the European Union has favored the emergence of the European dimension of tax evasion through double taxation, high heterogeneity manifested in national tax regimes and, so different levels of fiscal pressure, which led to multiple tax avoidance opportunities. 


\section{Definitions, Components, Trends and Effects}

\subsection{Definitions and Components}

- Tax avoidance. It is the phenomenon of legitimate minimization of taxes and maximization of income after tax, using methods included in the tax code. Companies avoid taxes by considering all legitimate tax deductions and credits and shielding tax revenues by establishing employee retirement plans and other means, all legal and according to the Internal Revenue Code or State Tax Codes.

- Tax loopholes. A tax loophole is "tax avoidance". Tax avoidance is a clause, a loophole or a hole in the tax laws that taxpayers can take advantage of to reduce their taxes. It is a way to avoid paying taxes, but since it is in the Tax Code it is not evasion. Because the tax code is so complex, tax experts have found ways to reduce taxes for their customers without breaking the law, taking advantage of parts of the law. If you are tempted to use a tax loophole, keep in mind that tax laws are complex and difficult to interpret. An honest and competent tax expert can relieve taxpayers of crossing the line from tax avoidance to tax evasion.

- Tax shield are another tax avoidance strategy. A tax shield is a deliberate use of tax-deductible expenses to offset taxable income.

- Tax evasion, uses illegal means to avoid paying taxes. Usually, tax evasion involves hiding or distorting income. This could be the concealment of income, which consists in not recording all the income in the accounting records or not declaring it to the tax authorities. Another way is to reduce the tax base by recording in accounting fictitious expenses from companies with "ghost" behaviour. Another way is to hide or not declare cash transactions or hide money in offshore accounts. Tax evasion is part of a general definition of tax fraud, which is the intentional unlawful non-payment of taxes.

- Fraud, can be defined as "an act of cheat or distortion" and this makes someone who avoids taxes - misleading Member States' tax administrations into revenue or expenditure.

- Transfer prices, are the prices at which a company transfers tangible assets, and intangible assets, or provide services to affiliated companies. Within the meaning of the OECD Report (Organisation for, Economic Co-Operation and Development) an "affiliated company" is a company that meets the conditions set out in Article 9, subparagraphs 1a) and 1b) of the OECD Model Tax Convention. Under these conditions, two companies are affiliated if one of the companies participates directly or indirectly in the management, control or capital of the other, or if "the same persons participate directly or indirectly in the management, control or, capital" of both companies (if both companies are under joint control). In order to steal the payment of the tax, the taxpayer turns to protected areas in fiscal terms. Gradually, tax and financial engineering schemes were developed by multinational companies through which there were different combinations based on tax avoidance or even tax evasion behaviours. Thus, a company can capitalize on the advantage offered by areas with reduced taxation by declaring income earned in another country in the form of invoicing by the mother company or subsidiary. The transfer pricing mechanism is a way for tax evasion to take shape. Frequent manifestations of this kind have led to the need to exercise strict fiscal controls in the consolidated financial statements of the 
group of companies, in particular in the light of the origin of the declared income and the tax regime applicable to them.

- Value Added Tax Evasion

For EU companies, VAT is levied on most sales and purchases of goods in the EU. In such cases, VAT is levied and is due in the EU country where the goods are consumed by the final consumer. VAT is also levied on services when they are provided in each EU country. VAT is not levied on exports of goods to nonEU countries. In such cases, VAT is levied and due in the country of importation and it is not necessary to declare any VAT as an exporter. However, when exporting goods, you will need to provide documentation as proof that the goods have been transported outside the EU. Such proof could be provided by presenting to the tax authorities a copy of an invoice, a transport document or an export customs record. This proof will have to be provided in order to be able to deduct in full any VAT receivable that was paid in a previous export transaction. Insufficient documentation may mean that the taxpayer is not entitled to a refund of VAT related to the export of goods.

Like any tax, VAT is vulnerable to evasion and fraud. Its credit and repayment mechanism offer unique opportunities to avoid taxation and tax evasion, and this has recently become a major concern in the European Union.

VAT avoidance and evasion transactions can take several forms:

- Sub-reported sales. A merchant can only report a portion of sales by counterfeiting records and accounts, or taxpayers may or may not issue an invoice. VAT invoices were issued, but not declared by their issuer.

- Avoid registration. Such cases are relatively few. These are companies that operate close to the level of turnover exemption at which registration becomes a mandatory VAT payer. A taxpayer could fragment his business so that each part of the business falls below the VAT exemption threshold.

- Incorrect classification of goods. When traders have sales of goods or services that are taxable at different rates of VAT, or some of them do not fall within the scope of the tax (items exempt under VAT). Merchants can reduce their debt by calculating a lower VAT Pro-Rate.

- Omission of self-deliveries. Refers to goods or services produced by the enterprise and consumed by the owner or employees, in principle taxable. This is a relatively unimportant category in the most developed economies.

- Tax collected but not remitted. This can be possible either through false accounting

(below reported sales, as above), by technical bankruptcy before the payment of the tax or in other ways. More specifically, the evasion of companies with "ghost" or "missing merchant" behaviour. These are companies registered for VAT purposes that collect VAT from customers but disappear before paying the tax.

\subsection{Trends and Effects}

In order to counter tax evasion, the tax authority must, of course, first identify transactions with a high tax risk. Although this is more difficult, it is generally easier than discovering tax evasion, because tax evasion by definition involves distorting the facts or intentionally concealing them from the authorities.

International tax evasion has developed in the context of over-directing investment flows to emerging countries. To ensure that foreign direct investment acts as an 
engine of economic growth, emerging countries have used, in addition to the low cost of labour, a tax advantage, providing incentives to foreign investors. This is also true within the EU because there are significant development gaps between the countries that make up the union.

Recently, many studies have been directed at the tax advantages that support absolutely artificial, inconsistent economic systems to attract foreign investors. In general, the analysis showed that foreign investments targeted only under tax advantages do not ensure solid economic growth, as they are temporary.

Regarding the EU, seven EU countries have been accused of being tax havens.

Countries such as Belgium, Cyprus, Hungary, Ireland, Luxembourg, Malta and the Netherlands are accused by the European Parliament of having the characteristics of a tax haven and facilitating aggressive tax planning. This is mentioned in a report issued by the European Parliament in the first half of 2019. The report, it was adopted by the European Parliament's General Assembly and it was prepared mainly by the European Parliament's Committee on Financial Crimes and Tax Evasion. The adoption of the report by the European Parliament gives it political weight.

The report by the European Parliament's Committee on Financial Crimes and Tax Evasion is based on data published by accounting and law firms, which revealed tax optimization operations built in some EU countries.. Tax optimization operations have allowed large companies such as Allergan, Apple, Disney, GlaxoSmithKline, IKEA, Koch Industries, Nike and Skype to create tax avoidance opportunities. The seven countries identified in the report include some of the smallest nations in Europe and together represent less than $9 \%$ of the total population of the European Union.

Petr Ježek, chair of the European Parliament's Committee on Financial Crimes and Tax Evasion, responsible for drafting the report, says the seven countries identified in the report have managed to facilitate aggressive tax planning practices over many years due to their power to block reforms. in the EU Council.

The seven countries identified in the commission's report include some of the smallest nations in Europe. Together they represent less than $9 \%$ of the total population of the European Union.

The adoption of such reforms requires the unanimous agreement of all EU Member States. Petr Ježek explains in the report the lack of unanimity, which is due to the fact that some EU countries "clearly take advantage of the unequal and unfair situation".

The report published by the European Parliament could lead to the elimination of opportunities for tax optimization and the imposition of EU regulations in the seven countries mentioned in the Commission's report.Therefore, companies wishing to benefit from reduced taxes without the risk of being affected by EU anti-tax evasion measures are advised to carry out operations in countries that have not been accused by the European Parliament of being tax havens. Este dată ca și exemplu, Bulgaria, ca țară membră UE cu cele mai mici cote ale impozitului pe venitul corporativ și al persoanelor fizice (ambele rate sunt de 10\%) și cele mai mici costuri cu forța de muncă din UE (5,30 EUR pe oră. Bulgaria este o locație excelentă pentru optimizarea fiscală, fără să fie necesară evitarea taxării, deoarece are cote de impozitare scăzute.

Tax revenues within the EU remain high compared to other advanced economies. 
In 2018, mandatory taxes and social contributions in the 27 Member States of the European Union (UE-27) (UE-27 represents the European Union without the United Kingdom) accounted for $40.2 \%$ of GDP. The tax burden (The tax burden is measured as tax revenue collected as a percentage of GDP) in the EU it is high compared to other advanced economies (Graph 1), almost 6 pp above the OECD average. In particular, it was almost $16 \mathrm{pp}$ above the level in the United States, which significantly reduced their income tax in 2018 (2.5 pp lower than in 2017), This decrease is mainly due to the decrease in income and property taxes. The United Kingdom also had a relatively low tax burden in 2018 (33,8\%), UE-27 it was 1 pp over UE-28 (EU-28 European Union and United Kingdom). The tax burden in the euro area $(40,5 \%)$ was higher than in UE-27 (EU-19 represents the euro area). Tax revenues from UE-27 as a percentage of GDP increased slightly in 2018, reaching $40,2 \%$ (0.2 pp higher than in 2017), see Graph 2 . The tax-GDP ratio in the euro area also rose slightly in 2018 to $40,5 \%$, i.e. a supplement of $0.2 \mathrm{pp}$ compared to 2017. In both the EU-27 and the euro area, tax revenues were higher in 2018 than at any time in the previous decade.

Tax revenues relative to GDP increased in most Member States (20 out of 27) in 2018, especially in Luxembourg (1.6 pp) and Romania (1.4 pp). The largest decreases were recorded in Denmark (0.9 pp) and Hungary (0.8 pp). In 2018, tax revenues were higher than in 2008 in 19 Member States, for example Greece with an increase of $7.1 \mathrm{pp}$, while Ireland recorded the largest decrease, $6.4 \mathrm{pp}$.

The tax burden in the EU differs greatly between Member States (Chart 3), countries such as France (46.5\%), Denmark (45.1\%) and Belgium (44.8\%) having the highest tax revenue relative to GDP, and countries such as Ireland (22.6\%) and Romania (26.3\%) have the lowest tax burden.



Graph 1: Tax revenue (including compulsory actual social contributions), EU and selected countries, 2018 ( $\%$ of GDP)

Source: European Commission, DG Taxation and Customs Union, based on Eurostat and OECD data. ( $\left.{ }^{*}\right)$ OECD data for JP and AU from 2017. 


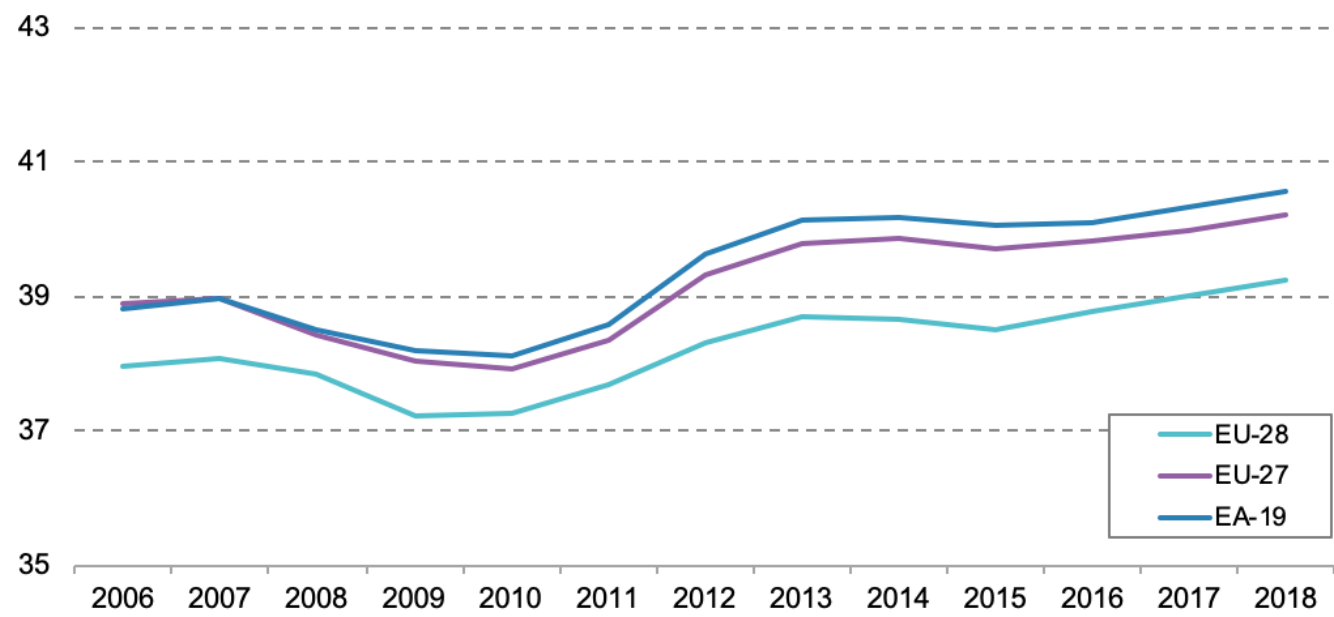

Graph 2: Tax revenue (including compulsory actual social contributions), EU-28, EU-27 and EA-19, 2006-2018 (\% of GDP).

Source: Eurostat (online data code: gov_10a_taxag).

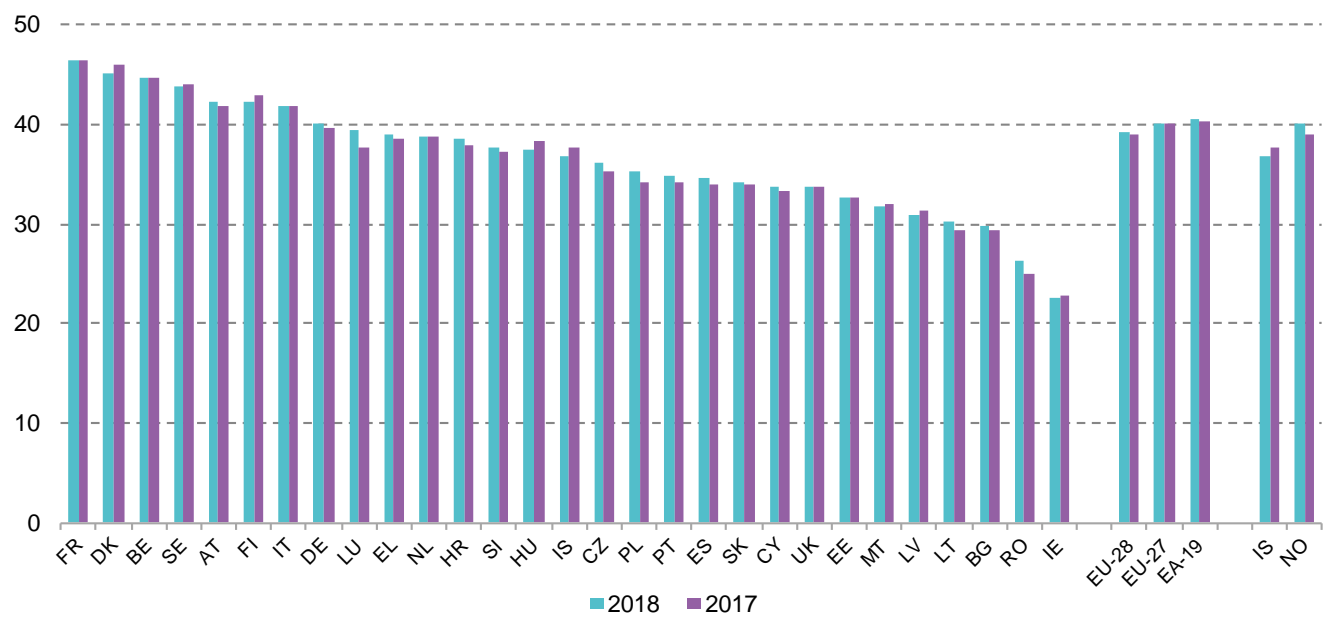

Graph 3: Tax revenue (including compulsory actual social contributions), 20172018 (\% of GDP)

Source: Eurostat (online data code: gov_10a_taxag).

A number of recent publications have linked budget revenue losses to tax evasion and tax avoidance in weaker EU economies. The phenomenon of evasion within these countries is related to the financial support that these countries receive through development aid. Many of these publications conclude that aid dependence could be significantly reduced if those countries were able to eliminate tax avoidance and tax evasion. 


\section{Conclusions}

Based on the analyses carried out by EU experts at Union level, the idea that concrete measures must be taken to reduce the economic gap between countries in order to combat tax evasion and tax avoidance is becoming increasingly clear. Another measure would be to reduce the tax burden in order to comply as voluntarily as possible. Tax administrations in the least developed Member States also need to work to eliminate legislative gaps and better monitor and collect taxes. Following the awareness of this state of affairs, the report A8-0170 / 2019 was presented to the European Parliament in 2019 " financial crimes, tax evasion and avoidance of tax obligations" by the Special Commission on Financial Crimes tax evasion and avoidance of tax obligations. Between the ideas that have emerged in this report we will refer to a few:

- often, existing tax rules cannot keep up with the growing speed of the economy; the current international and national tax rules were conceived mainly at the beginning of the twentieth century; states that there is now an urgent need to reform the rules so that international, European and national tax systems are adequate for the new economic, social and technological challenges of the 21 st century;

- a tax jurisdiction has control only over the tax issues related to its territory, while economic flows and some taxpayers, such as multinational corporations and people with high financial resources, operate worldwide;

- considers that fair taxation and the determined fight against tax fraud, tax evasion, aggressive tax planning and money laundering play a central role in creating a fair society and a strong economy, while defending the social contract and the rule of law;

- a fair and efficient tax system is essential to combat inequalities, not only by financing public spending to support social mobility, but also by reducing income inequalities;

- the most urgent priority is to reduce the fiscal gap resulting from tax fraud, tax evasion, aggressive tax planning and money laundering, as well as their impact on national and EU budgets, to ensure a level playing field and tax equity among all taxpayers and between them, to combat growing inequalities and to build confidence in the democratic policy-making process, by ensuring that fraudsters do not have a competitive tax advantage over honest taxpayers;

- Joint efforts at EU and national level are essential to defend the EU budget and national budgets against losses from unpaid taxes;

- only if tax revenues are collected fully and efficiently can states provide quality public services at affordable prices, including education, healthcare and housing services, security, crime control and emergency response, social security and social assistance, enforcement of labour and environmental standards, combating climate change, promoting gender equality, public transport and essential infrastructures, to stimulate and, if necessary, to stabilize socially balanced development, to move towards the achievement of sustainable development goals; 


\section{References:}

1. European Commission, Taxation and Customs Union (2011). Taxation trend in European Union, Focus on the crisis, The main impact on EU tax system [online]. Aveilable from: https://ec.europa.eu/eurostat/documents/3217494/5730669/KS-EU11-001-EN.PDF/fec0c5ff-e858-481c-904c-c291cf9804b8?version=1.0 [accessed 10 April 2021].

2. European Commission (2015). Communication on tax transparency to fight tax evasion and avoidance [online]. Aveilable from: https://eur-lex.europa.eu/legalcontent/EN/TXT/?uri=celex\%3A52015DC0136 [accessed 8 April 2021].

3. European Commission (2015). Study on structures of aggressive tax planning and indicators, Taxation Papers, Working Paper No. 61 [online]. Aveilable from: https://ec.europa.eu/taxation customs/sites/taxation/files/docs/body/taxation paper 61.pdf [accessed 8 April 2015].

4. European Commission (2020). The tax trend in the European Union [online]. Aveilable from: https://ec.europa.eu/taxation customs/business/economic-analysistaxation/taxation-trends-eu-union en [accessed 9 April 2021].

5. European Commission, Taxation and Customs Union (2021). Taxation data [online].

Available

from:

https://www.google.ro/url?sa=t\&rct=j\&q=\&esrc=s\&source=web\&cd=\&cad=rja\&uact =8\&ved=2ahUKEwjGsJaksKfvAhVMDewKHb9ABZEQFjAKegQIAxAD\&url=https\% 3A\%2F\%2Fec.europa.eu\%2Ftaxation customs\%2Fbusiness\%2Feconomicanalysis-taxation\%2Fdata-taxation en\&usg=AOvVaw0eAaREO 9D1lpDnnSURX2I [accessed 7 April 2021]

6. European Parliament, EPRS (2015). Bringing transparency, coordination and convergence to corporate tax policies in the European Union: I-Assessment of the magnitude of aggressive corporate tax planning, Study 2015 [online].Available from: https://op.europa.eu/en/publication-detail/-/publication/7b54c958-f63d-11 e5-852901aa75ed71a1/language-en [accesed 9 April 2021].

7. European Parliament, EPRS (2016). Bringing transparency, coordination and convergence to corporate tax policies in the European Union: II -Evaluation of the European Added Value of the recommendations in the ECON legislative owninitiative draft report, Study 2016 [online]. Available from: https://op.europa.eu/en/publication-detail/-/publication/7b54c958-f63d-11e5-852901aa75ed71a1/language-en [accessed 7 April 2021].

8. European Parliament (2018). Listing of tax havens by the EU [online]. Aveilable from: https://www.europarl.europa.eu/cmsdata/147404/7\%20-\%2001\%20EPRSBriefing-621872-Listing-tax-havens-by-the-EU-FINAL.PDF [accessed 6 April 2021]. 9. European Parliament (2019). Reporton financial crimes, tax evasion and tax avoidance[online]. Available

https://www.europarl.europa.eu/doceo/document/A-8-2019-0170 RO.html

[accessed 10 April 2021].

10. Financial-Monetary Research Center (2016). Analysis bulletin Nr.13/

September 2016 [online]. Aveilable from: http://cefimo.ase.ro/wp-

content/uploads/2018/02/CEFIMO Buletin $\mathrm{nr} 13$ 2016.pdf [accessed 6 April 2021]. 
11. Friedrich, S. and Dominik, H. E. (2000). The Shadow Economy in Western Europe [online]. Copenhagen: Rockwool Foundation Research Unit. Available from:https://www.researchgate.net/publication/227390150 The Shadow Economy [accessed 8 April 2021].

12. NoMoreTax (2020). Seven EU countries were accused in being tax havens [online].Available from: https://nomoretax.eu/seven-eu-countries-were-accused-inbeing-tax-havens [accessed 9 April 2021].

13. Lisowsky, P. (2010) Seeking shelter: Empirically modelling tax shelters using financial statement information [online]. Boston: University Qestrom School of Business, Available from: https://papers.ssrn.com/sol3/papers.cfm?abstract id=1089148\# [accessed 6 April 2021].

14. OECD (2015). Measuring and monitoring BEPS, Action 11 - 2015 final report [online]. Aveilable from: https://www.oecd.org/ctp/measuring-and-monitoring-bepsaction-11-2015-final-report-9789264241343-en.htm [accessed 20 February 2021]. 15. Petre, B., Sorin, C., and Ana, P. S.(2011). Forms of Tax Evasion in Romania. Analytical Perspective. Annals of the University of Petroşani, Economics [online], 11(1), pp33-42. Available from: https://www.upet.ro/annals/economics/pdf/2011/Brezeanu\%20-Celea-Stanciu.pdf [accessed 6 April 2021]. 